\title{
PENGUNGKAPAN EMOSI KEKECEWAAN \\ PADA ANAK USIA 1-3 TAHUN: SEBUAH KAJIAN PSIKOLINGUISTIK
}

\author{
(Expressions of Disappointment in 1-3 Years Old Children: \\ A Psycholinguistic Study)
}

\author{
Elen Azmiati, Nuryani \\ Universitas Islam Negeri Syarif Hidayatullah, Jakarta \\ Jalan Ir. H. Juanda No. 95, Ciputat, Tangerang Selatan \\ Pos-el: elennz.azmiati18@mhs.uinjkt.ac.id
}

(Naskah diterima 13 Desember 2020_Direvisi 16 Februari 2021—Disetujui 9 Maret 2021)

\begin{abstract}
This study describes the expressions of disappointment in 1-3 years children in a psycholinguistic perspective. The purpose of this study is to identify, analyze, and describe the language or speech spoken by children when they expressing disappointment. The method used is descriptive qualitative analysis using the theory of children's language acquisition in the field of Phonology and Syntax. Conversation data is obtained naturally by recording events when children experience disappointment. The results of the analysis show that children tend to express expressions of disappointment through nonverbal language in the form of roaring, screaming, and crying accompanied by explanatory speech. At the phonological level, children first master vowel sounds and several consonant sounds, such as $p, b, m, n$, and $h$. At the syntactic level, children aged 1; 4 (1 year; 4 months) have just mastered verbs and nouns. Children aged 2; 0 is able to speak two words that fall into the category of verbs, nouns, pronouns, and negative expressions. Children aged 2: 9 are able to speak two or more words that fall into the noun, verb, adjective, or adverb category.
\end{abstract}

Keywords: children, disappointment, psycholinguistics

\begin{abstract}
Abstrak
Penelitian ini memaparkan pengungkapan kekecewaan pada anak usia $1-3$ tahun dari kacamata psikolinguistik. Tujuan penelitian ini untuk mengidentifikasi, menganalisis, dan mendeskripsikan bahasa atau tuturan yang dituturkan oleh anakanak ketika dia mengalami kekecewaan. Metode yang digunakan adalah analisis kualitatif deskriptif dengan menggunakan teori pemerolehan bahasa anak dalam bidang fonologi dan sintaksis. Data percakapan diperoleh secara natural dengan cara merekam kejadiaan saat anak mengalami kekecewaan. Hasil analisis menunjukkan anak cenderung mengungkapkan ekspresi kekecewaan melalui bahasa nonverbal berupa raungan, teriakan, hingga tangisan yang disertai tuturan penjelas. Pada tataran Fonologi, anak lebih dahulu menguasai bunyi-bunyi vokal dan beberapa bunyi konsonan, seperti $p, b, m, n$, dan $h$. Pada tataran Sintaksis, anak usia 1; 4 (1 tahun; 4 bulan) baru menguasai verba dan nomina. Anak usia 2; 0 sudah mampu menuturkan dua kata yang masuk dalam kategori verba, nomina, pronomina, serta ungkapan negatif. Anak usia 2; 9 sudah mampu menuturkan dua atau lebih kata yang masuk kategori nomina, verba, adjektiva, atau adverbia.
\end{abstract}

Kata Kunci: anak-anak, kecewa, psikolinguistik 


\section{PENDAHULUAN}

Bahasa merupakan fenomena yang menarik untuk dijadikan objek penelitian karena karakteristik bahasa itu sendiri yang memiliki sifat keterbukaan, kebermaknaan, dan kecenderungan untuk dapat dipelajari. Karena sifat-sifat itulah, bahasa digolongkan menjadi salah satu kebutuhan pokok manusia untuk bertahan hidup selain makan dan bernapas. Dalam bertahan hidup, manusia melewati berbagai peristiwa tutur. Sebagaimana diketahui, peristiwa tutur merupakan berlangsungnya interaksi dalam satu atau lebih bentuk ujaran yang melibatkan dua pihak, yaitu penutur dan mitra tutur (Kurniati, 2020). Bahasa menjadi salah satu alat bagi manusia dalam berinteraksi dengan lingkungannya.

Pendapat lain yang disampaikan oleh Keraf (Saragi, 2019) yang menyatakan bahwa salah satu fungsi bahasa adalah alat untuk mengekspresikan sikap diri. Ekspresi yang dimunculkan melalui bahasa tercipta dalam bentuk peristiwa tutur. Terkait dengan peristiwa tutur, Kurniati menyampaikan bahwa peristiwa tutur merupakan gejala individual, bersifat psikologis, dan keberlangsungannya ditentukan oleh kemampuan bahasa penutur dalam menghadapi situasi tertentu (Kurniati, 2020). Hal ini terjadi pada setiap orang, tidak terkecuali bagi anak-anak. Dalam proses pemerolehan dan penggunaan bahasa, anak-anak menggunakan bahasa sebagai wujud ekspresi psikologis.

Bagi anak-anak, lingkungan menjadi salah satu faktor penting dalam menstimulus perkembangan psikologisnya. Mashar menyatakan bahwa perkembangan emosi terbentuk ketika anak mendapat stimulus berupa pengalaman emosi dari orang di sekitarnya (Mashar, 2015). Bentuk pengungkapan ekspresi emosi akan terlihat dalam pola tindak tutur yang disampaikan oleh penutur, baik secara verbal maupun nonverbal. Pengungkapan ekspresi verbal pada anak dapat ditunjukkan ketika berbicara atau menulis kata-kata yang bertujuan untuk mengungkapkan perasaannya. Ekspresi nonverbal dapat ditunjukkan melalui perubahan ekspresi wajah, vokal, perubahan fisiologis, atau gerak dan isyarat tubuh.

Penelitian yang dilakukan oleh psikolog Alber Mehrabian terhadap anakanak menunjukkan bahwa sekitar 55\% perasaan anak diungkapkan melalui isyarat nonverbal, seperti melalui ekspresi wajah atau sikap tubuh. Sementara itu, $38 \%$ perasaan disampaikan melalui nada suara. Sisanya, sebanyak 7\% diungkapkan melalui katakata. Dengan demikian, tidak heran anakanak cenderung menggunakan bahasa emosional nonverbal sederhana dalam mengungkapkan perasaannya, seperti menangis, berteriak, tertawa, tersenyum, atau mengoceh.

Sikap emosional anak ditunjukkan sesuai dengan situasi dan kondisi yang dihadapi. Sama dengan orang dewasa, pada kesempatan tertentu mungkin anak akan menunjukkan sikap-sikap tertentu, seperti perasaan senang atau tidak senang yang disebut juga dengan warna afektif. Emosi pada anak tidak hanya ditunjukkan dengan perasaan senang atau tidak senang, melainkan juga sedih, marah, cinta, takut, benci, dan cemas. Plutchik membagi emosi dasar menjadi delapan bagian, yaitu kegembiraan, kepasrahan, keterkejutan, kesedihan, kemuakan, kemarahan, dan antisipasi. Kemudian, dia kembali menyusun delapan emosi lanjutan dari emosi dasar tersebut, yaitu kecintaan, ketundukan, ketakjuban, kekecewaan, penyesalan, pelecehan, keagresifan, dan optimisme (Plutchik, 2003). 
Dalam ilmu linguistik, dikenal adanya subdisiplin ilmu yang bernama psikolinguistik. Psikolinguistik merupakan sebuah kajian dalam bidang kebahasaan yang memadukan antara disiplin ilmu Bahasa (linguistik) dan psikologi. Para ahli bahasa dan ahli psikologi pun turut mengutarakan pendapatnya mengenai disiplin ilmu ini. Aitchison mendefinisikan psikolinguistik sebagai suatu studi tentang bahasa dan minda. Kemudian, Lyons berpendapat bahwa dalam psikolinguistik terdapat aspek logika, filsafat bahasa, neurologi, ilmu kognitif, dan sosiolinguistik (Lyons, 1981). Bach menyatakan bahwa psikolinguistik adalah suatu ilmu yang meneliti bagaimana sebenarnya pembicara atau pemakai bahasa membentuk dan membangun sebuah kalimat bahasa (Nuryani dan Kurnia, 2013). Kajian psikolinguistik tidak hanya mengkaji atau mempelajari bahasa, tetapi juga bagaimana manusia memproduksi suatu ujaran dan menganalisis ujaran tersebut hingga membentuk suatu hal yang memiliki makna.

Kajian psikolinguistik tidak hanya mengaitkan antara bahasa dan pikiran, tetapi juga mengaitkannya dengan hal di luar kebahasaan, seperti pengaruh lingkungan sosial dan pengetahuan individu tentang dunia. Dardjowidjojo memerinci topik utama dalam mempelajari psikolinguistik menjadi (1) komprehensi, yaitu proses mental yang dilalui oleh manusia sehingga mereka dapat menangkap apa yang di katakan orang dan memahami apa yang dimaksud; (2) produksi, yaitu proses mental pada diri seseorang yang membuat seseorang dapat berujar seperti yang diujarkan; (3) landasan biologis dan neurologis yang membuat manusia bisa berbahasa; dan (4) pemerolehan bahasa, yakni bagaimana anak dapat memperoleh bahasa mereka (Dardjowidjojo, 2010).
Jean Piaget menyatakan bahwa bahasa bukanlah suatu ciri alamiah yang terpisahkan, melainkan salah satu di antara beberapa kemampuan yang berasal dari kematangan kognitif. Dalam psikolinguistik, teori kognitif lebih memandang bahasa secara mendalam. Para ahli bahasa memandang bahasa sebagai manifestasi dari perkembangan umum berupa aspek kognitif dan aspek afektif yang menyatakan tentang dunia. Titik awal teori kognitif ialah adanya anggapan terhadap kapasitas kognitif anak dalam menemukan struktur bahasa yang didengar di sekelilingnya. Dapat dikatakan pula bahwa struktur bahasa dapat timbul sebagai akibat dari interaksi yang terus-menerus antara anak dan lingkungan kebahasaannya. Oleh karena itu, lingkungan turut memengaruhi proses pemerolehan dan perkembangan bahasa pada anak.

Pemerolehan bahasa anak merupakan sebuah proses yang berlaku dalam otak manusia ketika memperoleh bahasa ibu. Ketika anak memperoleh bahasa ibu, terdapat dua aspek, yaitu aspek performa (aspek pemahaman dan pelahiran) dan aspek kompetensi (Nuryani dan Kurnia, 2013). Aspek pemahaman mengacu pada kemampuan anak dalam mengamati dan memersepsi kalimat yang didengar, sedangkan pelahiran mengacu pada kemampuan anak dalam mengucapkan kalimatkalimat yang telah didengar. Kemampuan inilah yang menjadi dasar kemampuan anak dalam berbahasa. Dalam studi ilmu linguistik, kemampuan ini dapat diklasifikasikan menjadi tiga komponen, yaitu kemampuan fonologis, kemampuan sintaksis, dan kemampuan semantik.

Scherleakens dalam Mar'at menjelaskan bahwa periode perkembangan bahasa anak dibagi menjadi empat periode, yaitu periode prelingual (usia $0-1$ tahun), periode lingual dini ( $1-2,5$ tahun), dan periode 
diferensiasi (usia 2,5-5 tahun). Perbedaan fase ini didasarkan pada ciriciri tertentu yang khas pada setiap periode, yakni (1) periode prelingual; anak memiliki 'bahasa sendiri', seperti mengoceh untuk berkomunikasi; (2) periode lingual dini; anak mulai mengucapkan perkataan yang pertama meskipun belum terlalu lengkap, seperti agi 'lagi', atoh 'jatuh', atit 'sakit', dan beberapa huruf konsonan seperti $r, s, k, j$, dan $t$. Pada periode ini, kemahiran berbahasa anak sangat cepat berkembang dan dapat dibagi manjadi tiga periode, yaitu periode kalimat satu kata (holophrase), periode kalimat dua kata, dan kalimat lebih dari dua kata. Periode ketiga ialah periode diferensiasi; kemampuan mencolok dalam periode ini ialah keterampilan anak dalam mengadakan diferensiasi dalam penggunaan kata-kata dan kalimat. Secara garis besar, ciri umum perkembangan bahasa pada periode ini ialah sebagai berikut.

a. Pada akhir periode, secara garis besar, anak telah menguasai bahasa ibunya.

b. Perkembangan fonologi boleh dikatakan telah berakhir, tetapi masih ada kesukaran pengucapan konsonan yang majemuk dan sedikit kompleks.

c. Perbendaharaan kata yang dimiliki anak sedikit demi sedikit mulai berkembang.

d. Fungsi bahasa untuk komunikasi anak benar-benar mulai optimal.

e. Mulai terjadi perkembangan di bidang morfologi yang ditandai dengan munculnya kata jamak, perubahan akhiran, perubahan kata kerja, dan lain-lain.

Beberapa penelitian yang relevan telah dilakukan. Salah satunya oleh Pujihastuti dkk. dengan judul "Pengungkapan Kegembiraan pada Anak Usia 3-5 Tahun dalam Kajian Psikolinguistik" (Pujihastuti, n.d.). Objek kajian yang dilakukan dalam penelitian tersebut hampir sama dengan yang penulis lakukan, yaitu pengungkapan emosi pada anak. Namun, objek penelitian yang digunakan Pujihastuti dkk. berupa pengungkapan emosi kegembiraan pada anak, sedangkan objek penelitian ini ialah pengungkapan kekecewaan pada anak.

Penelitian yang relevan selanjutnya ialah penelitian yang dilakukan oleh Watuna dengan judul "Penggunaan Bahasa dalam Mengekspresikan Emosi Kegembiraan dalam Film "Twilight Saga" oleh Stephenie Meyer: Suatu Analisis Psikolinguistik" (Watuna, 2014). Persamaan penelitian tersebut dengan penelitian yang dilakukan oleh peneliti, yaitu sama-sama meneliti ekspresi emosi dengan menggunakan kajian psikolinguistik. Perbedaannya terletak pada jenis emosi yang diteliti dan subjek penelitian yang digunakan. Dalam penelitian tersebut, subjek kajian yang digunakan ialah ekspresi kegembiraan yang tergambar dalam film "Twilight Saga", sedangkan subjek penelitian ini ialah anak usia 1-3 tahun dalam mengungkapkan kekecewaan.

Berdasarkan tinjauan pustaka tersebut dapat diketahui bahwa penelitian mengenai perasaan emosional pada manusia, khususnya perasaan kecewa pada anak-anak, belum banyak diteliti. Perasaan kecewa menjadi objek kajian yang kurang atau bahkan belum banyak diminati oleh para peneliti. Rasa kecewa pada anak merupakan salah satu rasa ketidakpuasan anak akibat tidak terkabulnya harapan atau keinginan terhadap suatu hal. Respons yang ditunjukkan anak pun berbeda-beda. Ada yang memberikan respons mengoceh, menangis, meraung, bahkan ada yang hanya diam. Dalam penelitian ini, peneliti akan mendeskripsikan dan menganalisis bagaimana tuturan yang dituturkan oleh anak-anak ketika mengalami kekecewaan. 


\section{METODE}

Penelitian ini menggunakan metode analisis kualitatif yang bersifat deskriptif. Metode kualitatif deskriptif merupakan metode penelitian yang tidak menghasilkan prosedur analisis statistik yang berkaitan dengan angka (Umrati dan Wijaya, 2020). Penelitian kualitatif berupaya menemukan pengetahuan terhadap subjek penelitian pada kondisi tertentu. Teknik pengumpulan data yang digunakan ialah teknik simak yang dilakukan dengan cara menyimak tuturan anak ketika mengalami kekecewaan. Menurut Sudaryanto, metode simak menggunakan teknik sadap sebagai teknik dasarnya (Mulyani, 2020).

Data primer dalam penelitian ini berupa percakapan langsung yang terjadi antara anak dan orang yang berada di sekitarnya. Prosedur dan teknik pengambilan data dilakukan dengan cara menyadap pembicaraan atau penggunaan bahasa yang dituturkan oleh anak-anak yang direkam dengan menggunakan aplikasi perekam di ponsel. Subjek penelitian ini ialah anak-anak dengan rentang usia $1-3$ tahun. Dalam hal ini, peneliti menggunakan teknik simak bebas cakap, yakni melakukan penyadapan dengan cara merekam kejadiaan tuturan saat anak mengalami kekecewaan. Percakapan yang telah direkam kemudian ditranskripsi. Adapun data yang dianalisis adalah data yang terkait dengan pengungkapan ekspresi dan emosi kekecewaan dengan menggunakan pendekatan psikolinguistik, yaitu pemerolehan bahasa anak dalam tataran fonologi dan sintaksis.

\section{PEMBAHASAN}

Perasaan kecewa merupakan perasaan yang sangat wajar dialami oleh siapa pun, termasuk anak-anak. Perasaan kecewa tidak sepenuhnya berkonotasi negatif.
Rasa kecewa justru dapat membuat anak meningkatkan keterampilan emosinya. Heinz Kohut, seorang pakar psikoanalisis, mengemukakan bahwa rasa kecewa atau frustrasi itu justru diperlukan anak untuk menjadi pribadi yang dewasa.

Menurut teori perkembangan Scherleakens anak dengan rentang usia 1-3 tahun masuk dalam kategori fase lingual dini. Dalam fase ini, anak belum mampu menguasai tata bahasa ibu. Hal ini disebabkan oleh organ ucap anak yang baru saja berfungsi. Kata yang diucapkan terdengar tidak terlalu jelas dan cenderung menggeneralisasikan secara berlebihan. Namun, pada tahap ini, anak sudah mampu membagikan perasaannya kepada orang lain secara lebih jelas, termasuk perasaan kecewa ketika yang terjadi tidak sesuai dengan keinginannya. Ketika keinginan itu tidak terwujud, biasanya anak akan mengucapkan sesuatu sebagai ungkapan emosinya. Hal itu sering membuat orang dewasa bingung memahaminya. Oleh karena itu, penelitian ini akan menganalisis tuturan kekecewaan yang alami oleh anak usia 1-3 tahun yang didasarkan pada teori pemerolehan bahasa anak.

\section{Aspek Fonologi}

Pada umumnya, sejak lahir, anak-anak telah mampu memproduksi bunyi-bunyi sederhana, seperti menangis. Pada tahun pertama, anak-anak sudah mampu membedakan bunyi perpetual seperti bunyi ketika berekspresi marah atau bersahabat. Aspek fonologis dalam pengungkapan kekecewaan anak muncul sebagai bentuk ekspresi spontan terhadap situasi atau kondisi tertentu. Adapun aspek fonologi yang terekam ketika anak sedang mengalami kekecewaan dapat dilihat pada tuturan berikut ini. 


\begin{tabular}{|c|c|c|}
\hline Konteks I & & $\begin{array}{l}\text { Nenek ingin mengajak Umar } \\
\text { (usia } 1 ; 4 \text { ) bermain ke taman } \\
\text { bermain anak-anak. }\end{array}$ \\
\hline Nenek & & $\begin{array}{l}\text { Umar, yuk kita main ke } \\
\text { taman, yuk! (Ketika Umar } \\
\text { hendak mengambil sandal, } \\
\text { tiba-tiba hujan turun) }\end{array}$ \\
\hline Nenek & & $\begin{array}{l}\text { Yah, hujan, Mar! Kita ke } \\
\text { tamannya besok aja, ya! }\end{array}$ \\
\hline Umar & & $\begin{array}{l}\text { Ниии.... (minta gendong } \\
\text { neneknya sembari menunjuk } \\
\text { ke luar) }\end{array}$ \\
\hline Nenek & & $\begin{array}{l}\text { Hujan, Sayang. Nanti basah } \\
\text { kalau kita main. Besok aja, } \\
\text { ya. }\end{array}$ \\
\hline Umar & & $\begin{array}{l}\text { Aa... аaа!! Ниии! Нии! Gi... } \\
\text { (meraung-raung } \\
\text { menunjuk ke luar) }\end{array}$ \\
\hline
\end{tabular}

Seperti disampaikan oleh Mashar, penggambaran emosi dapat disampaikan melalui dua cara, yakni verbal dan nonverbal. Dalam konteks peristiwa di atas, pengungkapan ekspresi kekecewaan disampaikan melalui dua cara tersebut. Pengungkapan kekecewaan secara verbal tergambar dari munculnya tangisan yang juga memunculkan fonem-fonem tertentu. Tangisan tersebut memunculkan bentuk fon hииии dan aа...aаa. Sementara itu, pengungkapan kekecewaan melalui nonverbal tergambar dari gerakan-gerakannya. Pada konteks di atas, subjek penelitian mengungkapkan kekecewaannya dalam bentuk nonverbal yang tergambar dengan meminta gendong, meraung-raung, dan menunjuk ke luar. Berdasarkan analisis tersebut, dapat disampaikan bahwa pada konteks I, subjek mengungkapkan ekspresi verbalnya dalam bentuk fonem.

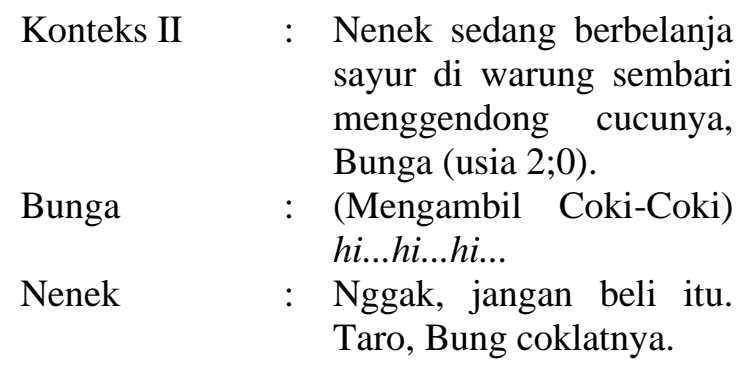

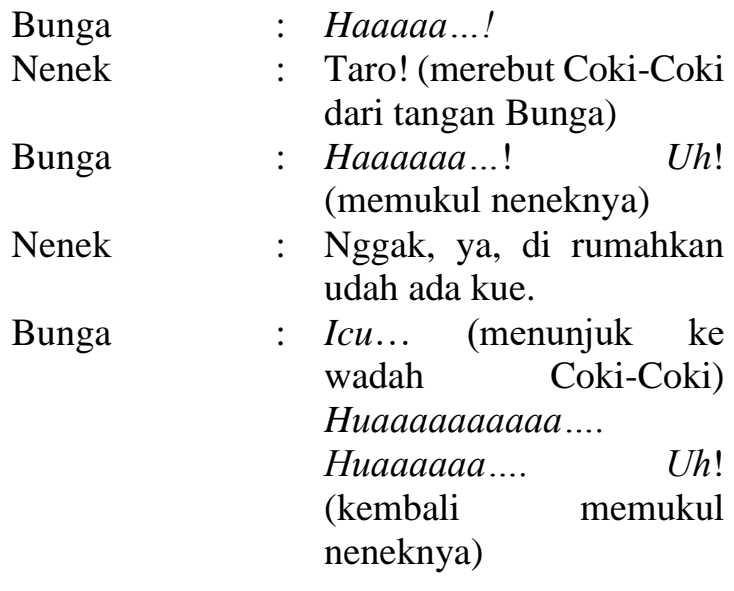

Konteks III : Di ruang tamu, Silvi (usia 2;9) sedang bermain ponsel milik ibu. Tibatiba, dari luar datang Helga, kakaknya, meminta ponsel untuk mengirim tugas sekolahnya.

Helga : Ipi, kakak pinjem hp-nya sebentar ya...

Silvi : Aa'aah...!

Helga : Sebentar doang, dah. Ini Kakak mau ngirim ini. (Lalu ponsel langsung diambil alih Kakak)

Silvi

Konteks I, II, dan III menunjukkan adanya aspek fonologi, yaitu berupa kumpulan fonem yang terangkai sehingga membentuk bunyi haaa! dan huuu! dalam konteks tuturan I dan bunyi haa'aah...! dan aaaaaah! dalam konteks tuturan II dan III. Rangkaian bunyi tersebut masuk ke dalam tataran fonologi karena tidak memiliki makna leksikal. Pada konteks tuturan I, rangkaian bunyi haaa! menandakan adanya ungkapan ekspresi kekecewaan Umar karena keinginannya untuk bermain di taman tidak terpenuhi akibat hujan. Rangkaian bunyi huиu! yang diungkapkan sembari menunjuk ke luar menandakan bahwa dia tetap ingin bermain meskipun hujan. Pada anak 
seusia Umar, pengetahuan mengenai dunia belum sepenuhnya mereka kuasai.

Pada konteks tuturan II, rangkaian bunyi haaaaaa...! dan huaaaa... mengungkapkan bentuk kekecewaan Bunga akibat keinginannya untuk membeli Coki-Coki tidak diwujudkan oleh Nenek. Pengungkapan kekecewaan Bunga juga ditunjukkan dengan cara memukul Nenek agar keinginannya terpenuhi.

Pada konteks tuturan III, rangkaian bunyi aa'aah...! mengungkapkan penolakan sekaligus bentuk usaha Silvi mempertahankan ponsel yang sedang digenggamnya. Rangkaian bunyi aaaaaaaaaaah! merupakan ungkapan bentuk kekecewaannya karena ponsel itu telah benar-benar diambil alih oleh kakaknya.

\section{Aspek Sintaksis}

Dardjowidjojo menyatakan bahwa anak memulai berbahasa dengan mengucapkan satu kata (atau bagian kata). Pada tahap ini, kata-kata yang diucapkan anak dapat merepresentasikan makna secara keseluruhan (Dardjowidjojo, 2010). Aspek sintaksis yang teramati ketika anak mengalami kekecewaan ialah sebagai berikut.

\begin{tabular}{|c|c|}
\hline Konteks IV & $\begin{array}{l}\text { Umar (usia } 1 ; 4 \text { ) bermain } \\
\text { beras di dapur. }\end{array}$ \\
\hline Mama Umar & $\begin{array}{l}\text { Umar ngapain? Gak, ya, } \\
\text { jangan main beras. }\end{array}$ \\
\hline Umar & : Ngak! \\
\hline Mama Umar & $\begin{array}{l}\text { Nggak si, tangannya } \\
\text { masih mainan aja. Yuk } \\
\text { main di depan. } \\
\text { (Menggendong Umar) }\end{array}$ \\
\hline Umar & $\begin{array}{l}\text { Nga..ngang..aaaaaahhh... } \\
!\end{array}$ \\
\hline Mama Umar & $\begin{array}{l}\text { : Hee... hee.. gak boleh } \\
\text { ngambek. (Lalu, Umar } \\
\text { menangis kencang) }\end{array}$ \\
\hline
\end{tabular}

Konteks V : $\quad$ Bunga (usia 2;0) saat itu sedang bermain di beranda rumah. Tiba-tiba ia lari keluar menyusul kakaknya yang sedang bermain di pinggir gang. Nenek Bunga pun segera mengejar.

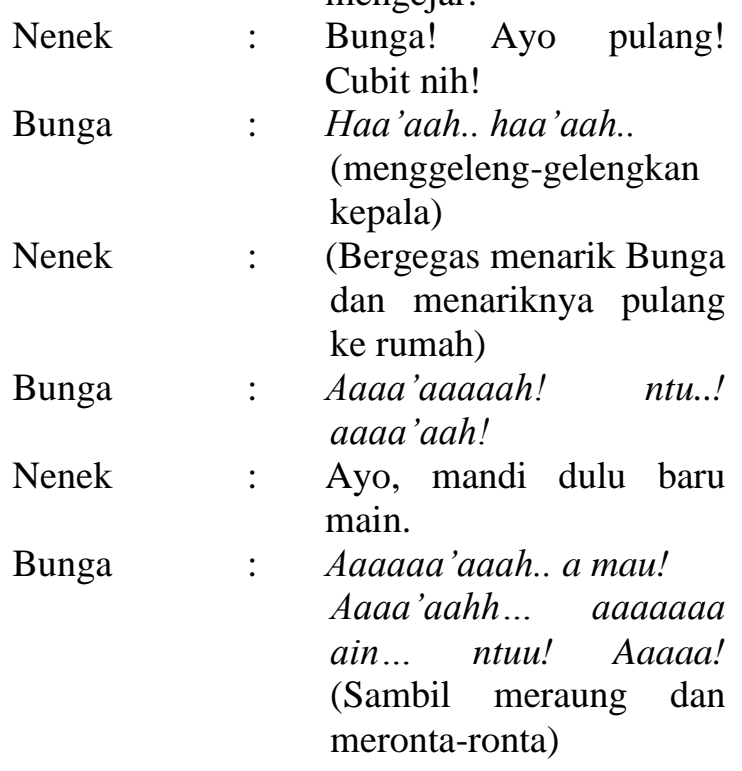

Data pada konteks IV menunjukkan bahwa pada tahap ini anak berada pada fase proses ujaran satu kata. Kata yang diujarkan berupa bentuk negatif, yakni kata ngak 'tidak'. Bentuk negatif yang diujarkan dimaksudkan sebagai upaya penolakan untuk berhenti bermain beras di dapur. Namun, upaya yang dilakukan oleh anak sia-sia karena dia tetap digendong oleh ibu untuk bermain di luar. Situasi demikian membuat anak mengalami kekecewaan. Lalu, anak pun berteriak dan menangis di depan ibunya sebagai bentuk pengungkapan kekecewaan yang dia alami. Pada tahap ini, anak sudah mampu mengujarkan kata yang masuk dalam kategori verba, nomina, atau ujaran bentuk negatif lainnya.

Selanjutnya, data yang terdapat dalam konteks $\mathrm{V}$ termasuk tuturan yang diucapkan anak yang sudah berada pada proses ujaran dua kata. Hal ini terlihat dalam ujaran kata $a . . . m a u$ dan ain ...ntuu. Ujaran itu dapat membuktikan bahwa anak telah mampu mengeluarkan ujaran 
dua kata. Pada tahap ini, anak sudah mampu menyatakan bentuk negatif, yaitu nggak, meskipun dalam proses mentalnya, kata ini lebih rumit, yaitu tidak, bukan, atau belum. Bentuk negatif ditunjukkan saat Bunga menuturkan kata a...mau yang dapat dipahami sebagai ungkapan penolakan 'tidak mau'. Pada tahap ini, anak sudah dapat mengucapkan kata-kata yang masuk dalam kategori nomina, pronomina, dan verba. Kata ain masuk dalam kategori verba dan kata ntuu masuk dalam kelas kata pronomina. Kata $a . . . m a u$ masuk dalam kategori verba negatif. Pengungkapan rasa kecewa Bunga terlihat saat dia meraung disertai dengan ungkapan penjelas, seperti kata a...mau dan ain ...ntuu.

Pada data konteks VI, kata yang diucapkan oleh anak sudah lebih jelas dibandingkan dengan konteks IV. Pada konteks VI itu, kemampuan anak dalam berbahasa sudah lebih menonjol, yaitu sudah lancar mengeluarkan ujaran yang mengandung lebih dari dua kata. Anak telah mampu mengucapkan kata dengan kategori nomina, verba, adjektiva, dan adverbia. Akan tetapi, dalam ujaran ini, kategori kelas kata yang menonjol ialah nomina. Hal ini terlihat pada kata mau amən dan amən ntu. Kata mau əmən masuk dalam kategori nomina. Begitu pula dengan kata omon ntu. Pengungkapan rasa kecewa ini tergambarkan melalui emosi Silvi saat berteriak disertai dengan ungkapan tambahan berupa kata mau əmən dan amən ntu... sehingga orang dewasa lebih mudah memahami apa yang dimaksudkan oleh anak.

Raungan, jeritan, atau tangisan merupakan salah satu cara anak dalam mengungkapkan rasa kekecewaannya. Kekecewaan anak juga dapat disebabkan adanya kebahagiaan yang dianggapnya direnggut. Perilaku seperti ini dilakukan oleh anak karena dia belum mampu mengelola dan mengungkapkan perasaannya dengan tepat. Hal ini disebabkan anak sedang berada dalam proses perkembangan, baik fisik, kebahasaan, maupun kepribadian.

\section{PENUTUP}

Berdasarkan analisis yang telah dilakukan, dapat disimpulkan bahwa ekspresi emosi kekecewaan anak-anak usia $1-3$ tahun sangat beragam. Mereka mengungkapkan kekecewaannya melalui cara verbal dan nonverbal. Pada tataran fonologi, anak-anak usia 1-3 tahun mengungkapkan kekecewaannya dalam bentuk bunyi yang diulang-ulang, seperti suara tangisan. Rangkaian bunyi yang digunakan anak ialah bunyi-bunyi vokal dan beberapa huruf konsonan, seperti $p$, $b, m, n, h$, dan $g$.

Sementara itu, pada tataran sintaksis, anak-anak usia $1-3$ tahun mengungkapkan kekecewaannya dalam bentuk kalimat. Kalimat yang muncul memiliki struktur yang sangat sederhana dan merupakan kalimat yang tidak lengkap. Dalam tataran sintaksis, perkembangan anak terlihat lebih pesat mengikuti rentang usia. Anak berusia 1; 4 sudah mampu menuturkan kata yang masuk dalam kategori kata verba, nomina, dan bentuk ujaran negatif, seperti kata tidak.

Anak yang berusia 2; 0 telah mampu menuturkan dua kata yang masuk dalam kategori verba, nomina, pronominal, dan bentuk ungkapan negatif. Pada anak usia 2; 9, ujaran yang diungkapkan bertambah, yaitu telah mencapai lebih dari dua kata. Kategori kata yang sudah dikuasainya pun bertambah, yaitu nomina, verba, adjektiva, dan adverbia. Namun, pada contoh kasus ini, kelas kata yang menonjol ialah nomina. Selain itu, dapat disimpulkan pula bahwa pada anak usia 1-3 tahun, ungkapan kekecewaan yang diperlihatkan lebih kepada bahasa 
nonverbal, yaitu berupa raungan, jeritan, dan tangisan yang disertai dengan beberapa bunyi atau kata yang dianggapnya dapat merepresentasikan perasaan atau keinginannya.

\section{DAFTAR PUSTAKA}

Dardjowidjojo, S. (2010). Psikolinguistik: Pengantar Pemahaman Bahasa Manusia. Jakarta: Obor.

Kurniati, A. (2020). Tindak Tutur Ekspresif dalam Novel My Stupid Bos 5 Karya Chaos@Work. Suar Betang, 14(1), 45-58.

Lyons, J. (1981). Language and Linguistics. Cambridge: Cambridge University Press.

Mashar, R. (2015). Emosi Anak Usia Dini. Jakarta: Prenadamedia Grup.

Mulyani. (2020). Praktik Penelitian Linguistik. Yogyakarta: CV Budi Utama.

Nuryani dan Kurnia, D. A. (2013). Psikolinguistik. Ciputat: Mazhab.
Plutchik, R. (2003). Emotion and Life, Perspectives from Psychology, Biology, and Evolution. Washington: APA.

Pujihastuti, E. et. al. (n.d.). Pengungkapan Kegembiraan pada Anak Usia 3--5 Tahun dalam Kajian Psikolinguistik. Jurnal Universitas Jenderal Sudirman.

Saragi, C. N. (2019). Wujud Tuturan Mengkritik Rocky Gerung terhadap Pemerintahan Presiden Joko Widodo. Suar Betang, 14(2), 117128.

Umrati dan Wijaya, H. (2020). Analisis Data Kualitatif Teori Konsep dalam Penelitian Pendidikan. Makassar: Sekolah Tinggi Theologia Joffray.

Watuna, E. (2014). Penggunaan Bahasa dalam Mengekspresikan Emosi Kegembiraan dalam Film Twilight Saga oleh Stephenie Meyer Suatu Analisis Psikolinguistik. Jurnal Unsrat. 